\title{
Analisis Activity Based Costing Dalam Penentuan Harga Pokok Perusahaan
}

\author{
Jusmani ${ }^{1}$, Andri Eko Putra ${ }^{2}$ \\ ${ }^{1}$ Fakultas Ekonomi dan Bisnis Universitas PGRI Palembang, jusmanitawil@yahoo.co.id \\ ${ }^{2}$ Fakultas Ekonomi dan Bisnis Universitas PGRI Palembang, andri ekoputra@yahoo.com
}

\begin{abstract}
Activity Based Costing is information that can provide accurate and timely information about work or activities that consume activity cost sources to achieve product and customer work objectives. $A B C$ is designed to measure the cost of product through activities. Costs will be measured from activity to product based on the demand for each product to activities during the production process, so that the costs incurred by each type of product will be seen more clearly. The system applies an activity accounting system to produce a more accurate calculation of the cost of product. Cost charging is a process of charging costs into a cost poll or from a cost poll to a cost object. Costs that are directly traceable to costs or cost objects can easily be linked economically. Indirect costs cannot be traced easily, and are even difficult to link economically from costs or cost polls to cost polls or cost objects. $A B C$ provides cost information associated with various activities to produce products, so that management will find it easy to get relevant information in making decisions regarding their various business activities.
\end{abstract}

Keywords: Activity Based Costing, Conventional Costing, Cost Driver.

\begin{abstract}
ABSTRAK
Activity Based Costing adalah suatu informasi yang dapat menyajikan secara akurat dan tepat waktu mengenai pekerjaan atau aktvitas yang mengkonsumsi sumber biaya aktivitas untuk mencapai tujuan pekerjaan produk dan pelanggan. $A B C$ dirancang untuk mengukur harga pokok produk melalui aktivitas-aktivitas. Biaya-biaya akan diukur dari aktivitas ke produk berdasarkan permintaan tiap-tiap produk terhadap aktivitas selama proses produksi, sehingga biaya yang timbul masing-masing jenis produk akan terlihat lebih jelas. Sistem tersebut menerapkan sistem akuntansi aktivitas untuk menghasilkan perhitungan harga pokok produk yang lebih akurat. Pembebanan biaya merupakan suatu proses pembebanan biaya ke dalam cost poll atau dari cost poll ke objek biaya. Biaya yang langsung dapat ditelusuri secara langsung ke biaya atau objek biaya secara mudah dapat dihubungkan secara ekonomi. Biaya yang tidak langsung tidak dapat ditelusuri secara mudah, dan bahkan sulit untuk dihubungkan secara ekonomi dari biaya atau cost poll ke cost poll atau objek biaya. ABC menyediakan informasi biaya yang dihubungkan dengan berbagai kegiatan untuk menghasilkan produk, sehingga manajemen akan memperoleh kemudahan dalam mendapatkan infomasi yang relevan dalam pengambilan keputusan yang menyangkut berbagai kegiatan bisnis mereka.
\end{abstract}

Kata kunci: Activity Based Costing, Conventional Costing, Cost Driver.

\section{A. PENDAHULUAN}

Activity Based Costing (ABC) merupakan pendekatan baru di dalam penentuan harga pokok produk (product costing). Sistem ini menyediakan informasi strategi yang relevan untuk keperluan penilaian profitabilitas produk jangka panjang dan produk lini (product lines) serta mendorong manajer untuk selalu mengevaluasi arus pekerjaan di dalam aktivitas organisasi. Dengan demikian, ABC merupakan sistem informasi yang datanya mengacu kepada produk dan aktivitas perusahaan.

Sebagai konsekuensinya, metodologi akuntansi manajemen yang baru harus berusaha untuk membedakan produk mana saja yang akan menambah nilai dan 
mana yang hanya menambah biaya saja. Dalam konteks ini, ABC diajukan sebagai salah satu metode yang menurut beberapa praktisi dianggap lebih bermanfaat dibandingkan dengan metode penentuan harga pokok konvensional (Conventional Costing).

Activity Based Costing (ABC) merupakan suatu sistem akuntansi yang berfokus pada aktivitas-aktivitas yang dilakukan untuk menghasilkan produk dan jasa. Dalam ABC, harus dilakukan penelitian aktivitas apa saja yang dilakukan untuk memproduksi produk. Ketelitian penemuan aktivitas akan menyebabkan ketelitian perhitungan harga pokok produk. Dasar pemikiran pendekatan penentuan biaya ini adalah bahwa produk atau jasa perusahaan dilakukan oleh aktivitas dan aktivitas yang dibutuhkan tersebut menggunakan sumber daya yang menyebabkan timbulnya biaya. Sumber daya dibebankan ke aktivitas, kemudian aktivitas dibebankan ke objek biaya berdasarkan penggunaannya.

\section{B. KAJIAN TEORI \\ a. Pengertian Activity Based Costing}

Secara umum pengertian Activity Based Costing System (ABC System) adalah suatu system biaya yang mengumpulkan biaya-biaya ke dalam aktivitas-aktivitas yang terjadi dalam perusahaan lalu membebankan biaya aktivitas dan produk atau jasa tersebut pada manajemen agar selanjutnya dapat digunakan untuk perencanaan, pengendalian biaya, dan pengambilan keputusan.

Menurut V. Wiratna Sujarweni (2015:122) Metode Activity Based Costing adalah sistem akumulasi biaya dan pembebanan biaya ke produk dengan menggunakan berbagai cost driver, dilakukan dengan menelusuri biaya dari aktivitas dan setelah itu menelusuri biaya dari aktivitas ke produk. Mengidentifikasi biaya aktivitas dan kemudian ke produk merupakan langkah dalam menyusun activity based costing system Hansen dan Mowen (2012).

Menurut Tunggal, (2011:435) Activity Based Costing adalah costing sistem yang menjadikan aktivitas individu sebagai dasar cost objeknya, metode ini mengkalkulasi biaya dari setiap aktivitas yang dilakukan untuk mempruduksi suatu produk atau jasa.

Menurut Riwayadi (2014:435) Activity Based Costing adalah costing system yang menjadikan aktifitas individu sebagai dasar cost object-nya. Metode ini mengkalkulasikan biaya dari setiap aktifitas yang dilakukan untuk memproduksi suatu produk atau jasa dan meng-assignnya kepada cost object (baik produk atau jasa).

Tujuan Activity Based Costing adalah untuk mengalokasikan biaya-biaya produksi berdasarkan aktivitas yang dilaksanakan, kemudian mengalokasikan biaya tersebut berdasarkan aktivitas-aktivitasnya.

\section{b. Konsep Dasar Activity Based Costing}

Activity Based Costing System adalah suatu system akuntansi yang terfokus pada aktivitas-aktivitas yang dilakukan untuk menghasilkan produk/jasa. Activity Based Costing menyediakan informasi perihal aktivitas-aktivitas dan sumber daya yang dibutuhkan untuk melaksanakan aktivitas-aktivitas tersebut. Aktivitas adalah setiap kejadian atau transaksi yang merupakan pemicu biaya (cost driver) yakni, bertindak sebagai faktor penyebab dalam pengeluaran biaya dalam organisasi. Aktivitas-aktivitas ini menjadi titik perhimpunan biaya. Dalam sistem ABC, biaya ditelusuri ke aktivitas dan kemudian ke produk. Sistem ABC mengasumsikan bahwa aktivitas-aktivitaslah yang mengkonsumsi sumber daya dan bukannya produk. 


\section{c. Struktur sistem Activity Based Costing}

Desain $A B C$ difokuskan pada kegiatan, yaitu apa yang dilakukan oleh tenaga kerja dan peralatan untuk memenuhi kebutuhan pelanggan. Kegiatan adalah segala sesuatu yang mengkonsumsikan sumber daya perusahaan. Dengan memusatkan perhatian pada kegiatan dan bukannya departemen atau fungsi, maka sistem ABC akan dapat menjadi media untuk memahami, memanajemen, dan memperbaiki suatu usaha. Ada dua asumsi penting yang mendasari metode Activity Based Costing System, yaitu:

1. Aktivitas-aktivitas yang menyebabkan timbulnya biaya.

Metode Activity Based Costing System bahwa sumber daya pembantu atau sumber daya tidak langsung menyediakan kemampuannya untuk melaksanakan kegiatan bukan hanya sekedar penyebab timbulnya biaya.

2. Produk atau pelanggan jasa.

Produk menyebabkan timbulnya permintaan atas dasar aktivitas untuk membuat produk dan jasa yang diperlukan berbagai kegiatan yang menimbulkan sumber daya untuk melaksanakan aktivitas tersebut.

Asumsi tersebut diatas merupakan konsep dasar dari ABC System, selanjutnya karena adanya aktivitas akan menimbulkan biaya, maka untuk dapat menjalankan usahanya secara efisien, perusahaan harus dapat mengelola aktivitasnya. Dalam hubungannya dengan biaya produk, maka biaya yang dikonsumsi untuk menghasilkan produk adalah biaya-biaya untuk aktivitas merancang, merekayasa, memproduksi, menjual dan memberikan pelayanan produk.

d. Cara pelaksanaan Activity Based Costing

Activity Based Costing dapat dilakukan dengan cara:

1. Mengidentifikasikan aktivitas.

2. Mengumpulkan semua biaya overhead yang berhubungan dengan semua aktifivitas dalam cost poll untuk semua aktivitas tersebut.

3. Membagi biaya total untuk setiap aktivitas, berdasarkan jumlah unit dari aktivitas yang di produksi untuk menghitung biaya per unit dari aktivitas yang disediakan.

4. Membebankan biaya aktivitas kesetiap cost objective dengan menggunakan unit aktivitas yang di produksi.

\section{e. Tujuan dan Peranan Activity Based Costing}

Tujuan Activity Based Costing digunakan untuk mengalokasikan biaya ke transaksi dari aktivitas yang dilaksanakan dalam suatu organisasi dan kemudian mengalokasikan biaya tersebut secara tepat ke produk sesuai dengan peranan aktivitas setiap produk.

Peranan Activity Based Costing system yaitu :

1. Pembebanan biaya tidak langsung dan pendukung

2. Pembebanan biaya dan alokasi biaya yaitu biaya langsung dan biaya tidak langsung.

\section{f. Manfaat Activity Based Costing}

Menurut Riwayadi (2014:440), manfaat dari Activity Based Costing yaitu:

1. ABC menyajikan biaya produk yang lebih akurat dan informatif, yang mengarahkan pengukuran protabilitas produk yang lebih akurat terhadap keputusan stratejik, tentang harga jual, lini produk, pasar, dan pengeluaran modal. 
2. $A B C$ menyajikan pengukuran yang lebih akurat tentang biaya yang dipicu oleh aktivitas, sehingga membantu manajemen meningkatkan nilai produk (product value) dan nilai proses (product value) dengan membuat keputusan yang lebih baik tentang desain produk, mengendalikan biaya secara lebih baik dan membantu perkembangan proyek peningkatan "value".

3. $A B C$ memudahkan manajer memberikan informasi tentang biaya relevan untuk pengambilan keputusan bisnis.

\section{g. Keunggulan Metode Activity Based Costing}

Keunggulan dari metode Activity Based Costing adalah sebagai berikut :

1. Suatu pengkajian $A B C$ dapat menyakinkan manajemen bahwa mereka harus mengambil sejumlah langkah untuk menjadi lebih kompetitif. Sebagai hasilnya mereka dapat berusaha untuk meningkatkan mutu sambil secara simultan berfokus pada mengurangi biaya. Analisis biaya dapat menyoroti bagaimana benar-benar mahalnya proses manufakturing, yang pada akhirnya dapat memicu aktivitas untuk mereorganisasi proses, memperbaiki mutu dan mengurangi biaya.

2. ABC dapat membantu dalam mengambil keputusan.

3. Manajemen akan berada dalam suatu posisi untuk melakukan penawaran kompetitif yang lebih bayar.

4. Dengan analisis biaya yang diperbaiki, manajemen dapat melakukan analisis yang lebih akurat mengenai volume, yang dilakukan untuk mencari break even atas produk yang bervolume rendah.

5. Melalui analisis data biaya dan pola konsumsi sumber daya, manajemen dapat mulai merekayasa kembali proses manufakturing untuk mencapai efisien dan lebih tinggi.

\section{h. Pengertian Cost Driver}

Landasan penting untuk menghitung biaya berdasarkan aktivitas adalah dengan mengidentifikasi pemicu biaya atau cost driver untuk setiap aktivitas. Cost driver merupakan faktor yang dapat menerangkan konsumsi biaya-biaya overhead. Faktor ini menunjukkan suatu penyebab utama tingkat aktivitas yang akan menyababkan biaya dalam aktivitas. Ada dua jenis cost driver, yaitu :

1. Cost driver berdasarkan unit

Cost Driver berdasarkan unit membebankan biaya overhead pada produk melalui penggunaan tarif overhead tunggal oleh seluruh departemen.

2. Cost Driver berdasarkan non unit

Cost Driver berdasarkan non unit merupakan faktor-faktor penyebab selain unit yang menjelaskan konsumsi overhead. Contoh Cost Driver berdasarkan unit pada perusahaan jasa adalah luas lantai, jumlah pasien, jumlah kamar yang tersedia.

\section{i. Perbedaan Sistem Activity Based Costing dengan Sistem Tradisional}

Menurut Firdaus Ahmad Dunia (2012 : 319) perbedaan penerapan Activity Based Costing dan Traditional Costing adalah pada cara pengalokasian biaya-biaya tidak langsung kepada objek biaya. Untuk biaya langsung, dapat dilakukan dengan cara pembebanan langsung kapada masing-masing objek biaya karena dapat dilakukan penelusuran secara mudah. Untuk biaya tidak langsung, tidak mungkin dilakukan penelusuran langsung pada objek biaya, karena banyak jenis biaya yang harus dibebankan tetapi tidak ditemukan hubungannya dengan objek biayanya. 
Pada traditional costing, biasanya seluruh biaya tidak langsung akan dikumpulkan dalam satu pengelompokkan biaya (cost pool), kemudian seluruh total biaya tersebut dialokasikan dengan satu dasar pengalokasian (cost allocation based) kepada suatu objek biaya. Pemilihan dasar pengalokasian biasanya berdasarkan hubungan sebab akibat yang paling mewakili sebagian besar biaya tidak langsung. Misalnya, jika biaya tidak langsung suatu perusahaan didominasi oleh biaya overhead pabrik yang sangat otomatis prosesnya, maka bisa saja dasar pengalokasian yang dipilih adalah jam kerja mesin.

Pada Activity Based Costing, seluruh biaya tidak langsung akan dikumpulkan dalam beberapa pengelompokkan biaya (cost pool) sesuai dengan aktivitas masingmasing yang berhubungan, kemudian masing-masing kelompok biaya tersebut dihubungkan dengan masing-masing aktivitas tersebut dan dialokasikan berdasarkan aktivitasnya masing-masing. Pemilihan kelompok biaya biasanya berdasarkan aktivitas yang sesuai dengan hierarki biaya dan hampir sama kegiatannya. Sedangkan utnuk pemilihan dasar alokasi adalah jumlah aktivitas dalam setiap kelompok biaya tersebut.

\section{j. $\quad$ Pengalokasian System Activity Based Costing}

Pengalokasian System Activity Based Costing dilakukan dalam dua tahap :

1. Tahap pertama : Pembebanan Biaya ke Aktivitas

Ada empat langkah yang harus dilakukan pada tahap ini yaitu :

a. Penggolongan berbagai aktivitas

Beberapa aktivitas diklasifikasikan kedalam beberapa dan kelompok yang mempunyai suatu fisik yang mudah dan jelas, serta cocok dengan segmensegmen proses produksi yang dapat dikelola.

b. Mengasosiasikan berbagai biaya dengan aktivitas

Yaitu menghubungkan setiap biaya dengan hubungan aktivitas.

c. Penentuan kelompok-kelompok biaya dan aktivitas

Pada tahap ini penentuan kelompok-kelompok biaya yang homogen adalah sekumpulan biaya overhead yang dibutuhkan secara logis dengan tugastugas yang dilaksanakan dan berbagai macam biaya tersebut dapat diterangkan oleh pemicu biaya tunggal dan mempunyai rasio yang sama untuk semua produk.

d. Penentuan tarif kelompok

Biaya overhead per unit pemicu biaya yang dihitung untuk semua kelompok aktivitas.

$$
\text { Tarif per unit }=\frac{\text { Jumlah aktivitas }}{\text { Cost Driver }}
$$

\section{Tahap kedua}

Dalam tahap ini setiap kelompok overhead ditelusuri ke berbagai jenis produk, ini dilaksanakan dengan menggunakan tarif kelompok yang dikonsumsi oleh setiap produk. Ukuran ini merupakan penyederhanaan kualitas pemicu biaya yang digunakan oleh setiap produk.

$$
\text { BOP yang dibebankan }=\text { tarif kelompok } X \text { penggunaan kegiatan }
$$




\section{k. Keterbatasan Acitvity Based Costing}

Menurut Tunggal (2011:440) meskipun Activity Based Costing memberikan alternatif penelusuran biaya ke produk individual secara lebih baik, tetapi mempunyai keterbatasan yang harus diperhatikan oleh manajer sebelum menggunakan untuk menghitung biaya produk :

1. Alokasi

Bahkan jika data aktivitas tersedia, beberapa biaya mungkin membutuhkan alokasi ke departemen atau produk berdasarkan ukuran volume yang arbiter sebab secara praktis tidak dapat ditemukan aktivitas yang dapat menyebabkan biaya tersebut. Contoh beberapa biaya untuk mempertahankan fasilitas, seperti membersihkan pabrik dan pengelolaan produksi.

2. Mengabaikan biaya

Keterbatasn lain Acitvity Based Costing adalah beberapa biaya yang diidentifikasi pada produk tertentu diabaikan dari analisis. Ativitas yang biayanyasering diabaikan adalah pemasaran, advertensi, riset, dan pengembangan, rekayasa produk, dan klaim garansi. Tambahan biaya secara sederhana ditambahkan ke biaya produk untuk menentukan biaya produk total.

3. Pengeluaran dan waktu yang dikonsumsi

System Activity Based Costing sangat mahal untuk dikembangkan dan diimplementasikan. Disamping itu juga membutuhkan waktu yang banyak seperti sebagian besar system akuntansi dan manajemen yang inovatif, biasanya diperlukan waktu lebih dari satu tahun untuk mengembangkan dan mengimplementasikan Activity Based Costing dengan sukses.

\section{Realitas Tentang Activity Based Costing System}

Realitas Tentang Activity Based Costing System adalah sebagai berikut:

1. Activity Based Costing System Adalah Analisis Biaya

Pada tahap perkembangan Activity Based Costing System digunakan untuk memperbaiki metode penentuan kos produk, maka sampai sekarang masih ada orang yang memandang Activity Based Costing System tidak lebih sebagai system akuntansi biaya yang fungsinya mengukur, mengklasifikasikan, dan mencatat data biaya, serta menyajikan laporan biaya kepada manajemen produk. Pandangan seperti itu berakar dari teknologi manual sebagian besar waktu proses akuntansi dihabiskan dalam kegiatan pengukuran, pengklasifikasian, pencatat, dan penyajian informasi biaya dalam laporan kos produk, sehingga waktu yang tersisa untuk menganalisa informasi biaya semakin sedikit.

Dengan teknologi informasi, proses pengukuran, pengklasifikasian, pencatatan dan biaya sangat mudah, cepat, akurat dilaksanakan dengan bantuan perangkat lunak komputer, sehingga waktu banyak tersisa bagi personel untuk melakukan analisis terhadap data yang tersedia dalam shared databased. Dengan teknologi informasi, data yang di sediakan oleh shared databased berupa biaya multidimensi, seperti dimensi jenis biaya, dimensi pusat pertanggung jawaban, dimensi aktivitas, dimensi produk atau jasa, dan dimensi costumer. Dari shared databased yang berisi data multidimensi tersebut. Pemakai informasi mampu melakukan analisis biaya multidimensi pula, sehingga terbuka kesempatan bagi pemakai informasi untuk melakukan pengambilan keputusan yang lebih jauh berkualitas, seperti pengurangan biaya melalui pengelolaan aktivitas, penentuan harga jual, analisis profiyabilitas produk dan jasa, pengukuran kinerja personel. 
2. Activity Based Costing System adalah system informasi biaya untuk segala macam organisasi.

Activity Based Costing System menyajikan aktivitas sebagai titik pusat kegiatan, informasi tentang aktivitas diukur, dicatat, dan disediakan dalam shared databased melalui ABC system. Oleh karena itu aktivitas dapat dijumpai baik diperusahaan manufaktur, jasa, dagang, serta organisasi sektor publik, dan organisasi nirlaba. Dengan $A B C$ system ini, untuk pertama kalinya perusahaan jasa dan perusahaan dagang serta organisasi nirlaba dapat memanfaatkan sistem informasi biaya yang sangat bermanfaat untuk mengurangi biaya dan penentuan secara akurat kos fitur produk dan jasa. Perusahaan manufaktur, jasa, dan dagang serta organisasi public dan organisasi nirlaba berkepentingan untuk mengurangi biaya melalui pengelolaan aktivitas, sehingga perusahaan dan organisasi tersebut membutuhkan system informasi biaya yang mampu menyediakan informasi berlimpah tentang aktivitas.

3. Activity Based Costing system Mencakup Seluruh Biaya.

Activity Based Costing System didesain untuk semua jenis organisasi dan menggunakan aktivitas sebagai basis untuk mengukur, mengklasifikasikan, mencatat dan menyediakan data biaya. ABC system berfokus pada pengurangan biaya dan tidak hanya terhadap biaya yang terjadi produk, sejak tahap desain hingga tahap purna jual.

4. Activity Based Costing System Berfokus ke Pengurangan Biaya.

Activity Based Costing System berfokus ke pengurangan biaya, dimana biaya hanya dapat berkurang jika personil melakukan tindakan terhadap sesuatu yang menjadi penyebab timbulnya biaya yaitu aktivitas. Activity Based Costing System menyediakan informasi tentang aktivitas, sehingga pengurangan biaya menjadi terwujud.

5. Activity Based Costing System Menyediakan Informasi bagi Seluruh Personil Organisasi.

Activity Based Costing System didesain dalam era teknologi informasi, dengan teknologi ini data biaya dan data operasi dicatat dan diklasifikasikan dalam shared databased. Dari shared databased ini informasi biaya dapat di akses oleh personil organisasi yang diberikan wewenang untuk itu, kemudian informasi yang dihasilkan oleh Activity Based Costing System bersifat multidimensi dan berupa informasi keuangan dan non keuangan.

6. Activity Based Costing System adalah sistem informasi biaya diera Teknologi informasi.

Activity Based Costing System didesain untuk diolah dengan teknologi informasi, oleh karena itu Activity Based Costing System memiliki karateristik sebagai berikut:

$>$ Data biaya dan operasi dicatat dalam akun multidimensi, paling tidak ada empat dimensi yang dicakup dalam catatan yaitu, pusat pertanggung jawaban, aktivitas,jenis biaya, dan biaya produk dan jasa.

> Data biaya dan data operasi disediakan dalam shared databased yang dapat diakses oleh karyawan dan manager.

> Informasi yang dihasilkan tidak terbatas pada informasi keuangan, namun mencakup pula informasi operasi.

$>$ Informasi yang dihasilkan bersifat multidimensi. 
7. Activity Based Costing System Mengubah Cara Melaksanakan Bisnis.

Activity Based Costing System merupakan sistem informasi biaya yang mengubah cara yang digunakan oleh manajemen dalam pengelolaan proses bisnis, jika dalam manajemen tradisional, pengelolaan proses bisnis di pecah-pecah dalam fungsi, dengan Activity Based Costing System pengelolaan bisnis dilaksanakan secara terpadu berbasis aktivitas. Pengelolaan berbasis aktivitas ini menyebabkan dua perubahan radikal yang lain, yaitu:

$>\quad$ Personil mengubah orientasi pengelolaan yang semula tertuju pada pencapaian tujuan fungsinya berubah kepemuasan kebutuhan customer.

$>\quad$ Inprovement berkelanjutan terhadap aktivitas menjadi motivasi personil dalam pengelolaan bisnis.

Dengan demikian Activity Based Costing System sebenarnya bukan masalah akuntansi biaya saja, namun jauh lebih luas dari itu. Activity Based Costing System merupakan sistem baru dalam pengelolaan proses bisnis. Keberhasilan implementasi Activity Based Costing System dapat diukur dari perubahan orientasi pengelolaan kepemuasaan kebutuhan customer dan pengelolaan ke improvement terhadap aktivitas yang digunakan untuk melayani customer.

\section{HASIL PENELITIAN PEMBAHASAN}

Berikut ini akan diilustarasikan bagaimana cara menghitung atau menganalisis Activity Based Costing (ABC), PT. Jaya Abadi, menjual 2 produk yaitu Piring dan Gelas, datanya akan disajikan sebagai berikut:

\begin{tabular}{|c|c|c|c|}
\hline \multirow{2}{*}{ Keterangan } & \multicolumn{3}{|c|}{ Produk } \\
\hline & & iring & Gelas \\
\hline Volume produksi & & 20.000 & 80.000 \\
\hline Harga Jual & $\mathrm{Rp}$ & 24.000 & Rp 12.000 \\
\hline Biaya Utama & $\mathrm{Rp}$ & 12.000 & Rp 6.000 \\
\hline Jam Kerja Langsung & & 7.500 & 15.000 \\
\hline
\end{tabular}

Akuntan manajemen PT Jaya Abadi mengidentikasi aktivitas cost yang dianggarkan, datanya sebagai berikut:

\begin{tabular}{|l|c|}
\hline \multicolumn{1}{|c|}{ Aktivitas } & \multicolumn{2}{|c|}{ Anggaran Cost } \\
\hline Rekayasa & $\mathrm{Rp} 600.000$ \\
\hline Set up & $\mathrm{Rp} 2.000 .000$ \\
\hline Perputaran mesin & $\mathrm{Rp} 6.000 .000$ \\
\hline Pengemasan & $\mathrm{Rp} 400.000$ \\
\hline Total & $\mathrm{Rp} \mathbf{9 . 0 0 0 . 0 0 0}$ \\
\hline
\end{tabular}

Aktivitas sesungguhnya produk Piring dan Gelas, disajikan data sebagai berikut:

\begin{tabular}{|l|r|r|r|}
\hline \multirow{2}{*}{\multicolumn{1}{|c|}{ Aktivitas }} & \multicolumn{2}{|c|}{ Konsumsi/Realisasi } & \multirow{2}{*}{ Total } \\
\cline { 2 - 3 } & \multicolumn{1}{c|}{ Piring } & \multicolumn{1}{c|}{ Gelas } & \\
\hline Rekayasa (jam) & 12.000 & 18.000 & 30.000 \\
\hline Set up (jam) & 800 & 1.200 & 2.000 \\
\hline Perputaran mesin (jam) & 100.000 & 200.000 & 300.000 \\
\hline Pegemasan & 10.000 & 40.000 & 50.000 \\
\hline
\end{tabular}


Dari data biaya diatas, kita akan menghitung atau menganalisis biaya perusahaan dengan menggunakan metode tradisional (Konvensional) dan metode ABC (Activity Based Costing)

a. Menghitung biaya per unit menggunakan metode tradisional

Total Jam kerja langsung = Jam kerja langsung Piring + Jam kerja langsung Gelas

$$
=7.500+15.000=22.500
$$

Tarif Overhead Pabrik : Jam Kerja Langsung

$$
=\text { Rp. } 9.000 .000: 22.500=\text { Rp. } 400 / J K L
$$

Biaya Overhead yang di bebankan

\begin{tabular}{|l|c|r|rr|}
\hline Produk & $\begin{array}{c}\text { Total } \\
\text { (Biaya JKL per unit X jam kerja } \\
\text { langsung }\end{array}$ & Unit & \multicolumn{2}{|c|}{$\begin{array}{c}\text { Overhead/Unit } \\
\text { (Total:Unit) }\end{array}$} \\
\hline Piring & Rp $3.000 .000(\mathrm{Rp} 400 \times 7.500)$ & 15.000 & $\mathrm{Rp}$ & 200 \\
\hline Gelas & $\mathrm{Rp} 6.000 .000(\mathrm{Rp} 400 \times 15.000)$ & 60.000 & $\mathrm{Rp}$ & 100 \\
\hline
\end{tabular}

\begin{tabular}{|c|c|c|}
\hline Keterangan & Piring & Gelas \\
\hline Biaya Utama & $\begin{array}{r}R p 180.000 .000 \\
(\mathrm{Rp} 12.000 \times 15.000)\end{array}$ & $\begin{array}{r}R p 360.000 .000 \\
(\mathrm{Rp} 6.000 \times 60.000)\end{array}$ \\
\hline Biaya Overhead & $\begin{array}{cr}R p & 6.000 .000 \\
(R p 400 \times 15.000)\end{array}$ & $\begin{array}{c}R p \quad 24.000 .000 \\
(R p 400 \times 60.000)\end{array}$ \\
\hline Total Biaya & Rp 186.000 .000 & $\mathrm{Rp} 384.000 .000$ \\
\hline Unit Produksi & 20.000 & 80.000 \\
\hline Biaya/Unit & 9.300 & 4.800 \\
\hline
\end{tabular}

Menghitung biaya per unit produk

\section{b. Menghitung biaya per unit menggunakan metode ABC (activity based costing)}

Menghitung Tarif Aktivitas

\begin{tabular}{|l|l|r|cr|}
\hline \multicolumn{1}{|c|}{ Aktivitas Piring } & Total Biaya & Konsumsi Aktivitas & \multicolumn{2}{c|}{ Tarif Aktifitas } \\
\hline Rekayasa (jam) & $\mathrm{Rp} 600.000$ & 30.000 & $\mathrm{Rp}$ & 20 \\
\hline Set up (jam) & $\mathrm{Rp} 2.000 .000$ & 2.000 & $\mathrm{Rp}$ & 1.000 \\
\hline Perputaran mesin (jam) & $\mathrm{Rp} 6.000 .000$ & 300.000 & $\mathrm{Rp}$ & 20 \\
\hline Pegemasan & $\mathrm{Rp} 400.000$ & 50.000 & $\mathrm{Rp}$ & 8 \\
\hline Total & $\mathrm{Rp} \mathbf{9 . 0 0 0 . 0 0 0}$ & $\mathbf{3 8 2 . 0 0 0}$ & $\mathbf{R p}$ & $\mathbf{1 . 0 4 8}$ \\
\hline
\end{tabular}

Biaya Overhead yang dibebankan

Produk Piring

\begin{tabular}{|l|rr|r|ll|lr|}
\hline \multicolumn{1}{|c|}{ Aktivitas } & \multicolumn{2}{c|}{ Tarif } & \multicolumn{2}{c|}{ Konsumsi } & \multicolumn{2}{c|}{ Total BOP } & \multicolumn{2}{c|}{ BOP/Unit } \\
\hline Rekayasa (jam) & $\mathrm{Rp}$ & 20 & 12.000 & $\mathrm{Rp}$ & 240.000 & $\mathrm{Rp}$ & 20 \\
\hline Set up (jam) & $\mathrm{Rp}$ & 1.000 & 800 & $\mathrm{Rp}$ & 800.000 & $\mathrm{Rp}$ & 1.000 \\
\hline Perputaran mesin (jam) & $\mathrm{Rp}$ & 20 & 100.000 & $\mathrm{Rp} 2.000 .000$ & $\mathrm{Rp}$ & 20 \\
\hline Pegemasan & $\mathrm{Rp}$ & 8 & 10.000 & $\mathrm{Rp}$ & 80.000 & $\mathrm{Rp}$ & 8 \\
\hline Total & $\mathrm{Rp}$ & $\mathbf{1 . 0 4 8}$ & $\mathbf{1 2 2 . 8 0 0}$ & $\mathrm{Rp} \mathbf{3 . 1 2 0 . 0 0 0}$ & $\mathrm{Rp} \mathbf{1 . 0 4 8}$ \\
\hline
\end{tabular}


Produk Gelas

\begin{tabular}{|c|c|c|c|c|c|}
\hline Aktivitas Piring & & & Konsumsi & Total BOP & BOP/Unit \\
\hline Rekayasa (jam) & $\mathrm{Rp}$ & 20 & 18.000 & 180.000 & $R p$ \\
\hline Set up (jam) & $\mathrm{Rp}$ & 1.000 & 1.200 & Rp $\quad 600.000$ & Rp 1.000 \\
\hline Perputaran mesin & $\mathrm{Rp}$ & 20 & 200.000 & Rp 2.000.000 & $\mathrm{Rp}$ \\
\hline Pegemasan & $\mathrm{Rp}$ & 8 & 40.000 & Rp 160.000 & $R p$ \\
\hline Total & $\mathbf{R p}$ & 1.048 & 249.200 & Rp 2.940 .000 & Rp 1.048 \\
\hline
\end{tabular}

Menghitung biaya per unit produk

\begin{tabular}{|l|r|rr|}
\hline \multicolumn{1}{|c|}{ Keterangan } & \multicolumn{1}{c|}{ Piring } & \multicolumn{2}{c|}{ Gelas } \\
\hline Biaya Utama & Rp 180.000 .000 & $\mathrm{Rp} 360.000 .000$ \\
\hline Biaya Overhead & $\mathrm{Rp} 20.960 .000$ & $\mathrm{Rp} 83.840 .000$ \\
\hline Total Biaya & $\mathrm{Rp} 200.960 .000$ & $\mathrm{Rp} 403.840 .000$ \\
\hline Unit Produksi & 20.000 & & 80.000 \\
\hline Biaya/Unit & Rp $\quad \mathbf{1 0 . 0 4 8}$ & Rp & $\mathbf{5 . 0 4 8}$ \\
\hline
\end{tabular}

Terjadinya selisih harga dikarenakan pada metode Activity Based Costing, terdapat pada pembebanan biaya overhead pada masing-masing produk. Pada metode akuntansi biaya tradisional biaya overhead pada masing-masing produk hanya dibebankan pada satu cost driver saja. Akibatnya cenderung terjadi distorsi pada pembebanan biaya overhead. Sedangkan pada metode ABC, biaya overhead pada masing-masing produk dibebankan pada banyak cost driver. Sehingga dalam metode $A B C$, telah mampu mengalokasikan biaya aktivitas ke produk secara tepat berdasarkan konsumsi masing-masing aktivitas.

Kelemahan dari metode tradisional yang digunakan adalah perhitungannya kurang akurat dalam pembebanan biaya, sehingga mengakibatkan kesalahan penentuan biaya, pembuat keputusan, perencanaan dan pengendalian.

Untuk mengatasi kelemahan tersebut sebaiknya Perusahaan menggunakan metode activity based costing karena dengan menggunakan activity based costing akan diperoleh informasi biaya produk yang lebih akurat. Selain itu, perusahaan juga dapat mengetahui kontribusi laba dari masing-masing kelas kamar, sehingga hal ini dapat memberikan informasi yang akurat bagi kebijakan manajemen dalam rangka pengembangan perusahaan.

\section{KESIMPULAN}

a. ABC umumnya diaplikasikan pada perusahaan-perusahaan manufaktur, dan dapat juga digunakan untuk organisasi jasa dan non-profit. Banyak perusahaan telah mengembangkan dan mengimplementasikan sistem ABC, Organisasi jasa dan non-profit memiliki karakteristik khusus yang membedakan mereka dengan perusahaan manufaktur. Hasil keluaran seringkali sukar untuk didefinisikan, permintaan untuk produk jasa lebih sulit untuk diprediksi, dan biaya overhead serta biaya tak langsungnya sulit untuk dihubungkan dengan produk ataupun hasil keluaran jasanya.

b. $A B C$ amat erat dihubungkan dengan manajemen biaya strategis. $A B C$ mengalokasikan biaya terhadap produk atau pelanggan sesuai dengan sumber daya yang mereka konsumsi. Hal ini menujukkan kegiatan mengkonsumsi 
sumber daya dan bagaimana produk atau pelanggan memicu terjadinya kegiatan. ABC menjelaskan sebuah perusahaan sebagai suatu rangkaian kegiatan yang mana kinerjanya didesain untuk dapat memenuhi kebutuhan pelanggan. la menyediakan informasi bagi para manajer untuk dapat mengatur kegiatan yang dapat meningkatkan tingkat kompetitif perusahaan dan untuk meraih sasaran strategisnya.

c. Kegiatan ditentukan berdasarkan pilihan strategis. Perusahaan yang sukses meletakkan sumber dayanya pada kegiatan yang bisa menghasilkan keuntungan strategis terbesar. ABC membantu manajer untuk memahami hubungan antara strategi perusahaan dengan aktivitas dan sumber daya yang diperlukan untuk dapat menjalankan strategi. Keunggulan dalam hal biaya adalah strategi bisnis untuk menghasilkan keunggulan kompetitif.

\section{DAFTAR PUSTAKA}

Firdaus, A. Dunia, Wasilah, Abdullah, 2012, Akuntansi Biaya, Salemba Empat, Jakarta.

Riwayadi, 2014, Akuntansi Biaya, Salemba Empat, Jakarta.

Tunggal, Amin Widjaya. 2011. Dasar-Dasar Akuntansi Biaya dan Manajemen, Jakarta : Harvindo.

V. Wiratna, Sujarweni, 2015, Akuntansi Biaya, Pustaka Baru Press, Yogyakarta. 